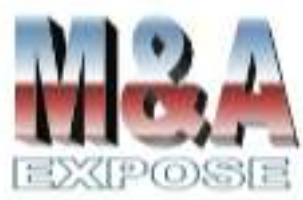

http://jurnal.usahid.ac.id/index .php/accounting
${ }^{1}$ Fakultas Ekonomi Universitas Serang Raya nanaumdianaunsera@amail.com

\section{Pengaruh Arus Kas dan Laba Akuntansi terhadap Abnormal Return pada Perusahaan Manufaktur di Indonesia}

\author{
Nana Umdiana ${ }^{1}$, Sintia Paradiba
}

\section{Abstrak}

Penelitian ini bertujuan untuk mengetahui pengaruh arus kas dan laba akuntansi terhadap abnormal return saham pada perusahaan manufaktur yang terdaftar di Bursa Efek Indonesia. Jenis penelitian ini adalah kuantitatif kausalitas dengan menggunakan metode analisis regresi linear berganda. Populasi penelitian ini sebanyak 142 perusahaan manufaktur. Teknik purposive sampling memperoleh sebanyak 46 perusahaan sebagai sampel. Berdasarkan hasil penelitian dapat disimpulkan bahwa arus kas secara parsial berpengaruh negatif signifikan terhadap abnormal return saham. Sedangkan laba akuntansi secara parsial berpengaruh positif signifikan terhadap abnormal return saham. Arus kas dan laba akuntansi secara simultan berpengaruh positif signifikan terhadap abnormal return saham.

Kata kunci : arus kas, laba akuntansi, abnormal return, perusahaan manufaktur.

\section{Abstract}

This study aims to determine the effect of cash flow and accounting profit towards abnormal return on manufacture companies listed on the Indonesian Stock Exchange. The type of this research is quantitative causality using the method of multiple linear regression analysis. The population of this study were 142 manufacture companies. The purposive sampling technique obtained as many as 46 companies as samples. Based on the results of the study it can be concluded that the cash flow partially has a significant negative effect on stock abnormal returns. While accounting profit partially has a significant positive effect on stock abnormal returns. Cash flow and accounting profit simultaneously have a significant positive effect on stock abnormal returns.

Keywords : cash flow, accounting profit, abnormal return, manufacture companies. 
Pengaruh Arus Kas dan Laba Akuntansi ...

Nana Umdiana, Sintia Paradiba

\section{PENDAHULUAN}

Pasar modal dimanfaatkan oleh entitas sebagai tempat untuk mencari dana lebih yang dapat digunakan untuk modal tambahan dalam rangka memperluas usaha, karena ada beberapa entitas yang kurang mampu memperluas usaha hanya dari modal sendiri. Pasar modal merupakan tempat yang sangat efektif untuk menyalurkan dan menginvestasikan dana, entitas yang menerima dana investasi akan memberikan deviden atau keuntungan kepada investor, adanya ketidakpastian pengembalian pada setiap investasi yang berlangsung tersebut investor harus selalu mempertimbangkan return dan resiko atas investasinya.

Setiap investor pasti tertarik untuk berinvestasi pada perusahaan yang dapat memberikan return yang tinggi tanpa melupakan resiko resiko yang harus dihadapinya. Ketika para investor mampu menanggulangi segala resiko yang akan muncul, yakin bahwa investasinya sukses sehingga mampu memperkirakan sebuah return, investor harus kembali lagi menganalisis tentang munculnya abnormal return. Munculnya abnormal return menunjukkan ketidakstabilan akan return yang telah diperkirakan, yang dapat menurunkan kepercayaan investor untuk menginvestasikan dananya. Selain itu efisiensi pasar diuji dengan melihat return tidak wajar atau abnormal return yang terjadi. Pasar dikatakan tidak efisien jika satu atau beberapa pelaku pasar dapat menikmati return tidak normal dalam jangka waktu yang cukup lama (Hartono, 2014). Setiap investasi membuat para investor harus mempertimbangkan dan menganalisa setiap informasi informasi yang ada pada entitas yang membutuhkan investasi untuk memaksimalkan tingkat return, karena informasi bermakna jika informasi tersebut mampu merubah kepercayaan investor.

Dalam hal ini akuntansi ikut berperan dalam menyediakan informasi berupa laporan keuangan yang diperlukan untuk bahan pertimbangan pengambilan keputusan para investor. Pelaporan komponen keuangan merupakan salah satu perwujudan atas pertanggungjawaban manajemen dalam pengelolaan sumber daya perusahaan kepada pihak-pihak yang berkepetingan sebagai pertimbangan dalam membuat keputusan investasi. Laporan keuangan yang dianggap menjadi perhatian utama para calon investor adalah laporan arus kas dan laporan laba rugi. Laporan arus kas memberikan informasi mengenai aliran dari semua sumber ekonomi yang diperoleh dan digunakan dalam kegiatan perusahaan, sedangkan laporan laba rugi menyediakan kinerja perusahaan dalam menghasilkan laba.

Penelitian ini akan menguji apakah publikasi laporan keuangan berupa informasi arus kas dan laba akuntansi mempunyai pengaruh terhadap abnormal return saham perusahaan tersebut. Umdiana, N. (2014) meneliti pengaruh kandungan informasi laba, arus kas operasi, deviden, ukuran perusahaan dan tingkat inflasi terhadap abnormal return menyimpulkan adanya pengaruh signifikan informasi laba dan deviden terhadap abnormal return, sedangkan arus kas operasi, size perusahaan dan inflasi tidak berpengaruh signifikan terhadap abnormal return. Agustina dan Kianto (2012) meneliti pengaruh informasi laba akuntansi terhadap abnormal return pada perusahaan yang tergabung dalam indeks LQ-45 mengambil kesimpulan bahwa laba bersih berpengaruh negatif signifikan terhadap abnormal return saham. Amalia, et. al. (2012) meneliti pengaruh laba, pengungkapan corporate social responsibility, dan profitabilitas terhadap abnormal return saham dengan kesimpulan bahwa laba dan pengungkapan corporate social responsibility berpengaruh 
positif terhadap abnormal return saham, sedangkan profitabilitas berpengaruh negatif terhadap abnormal return saham.

Nelvianti (2012) meneliti pengaruh informasi laporan arus kas, laba, dan ukuran perusahaan terhadap abnormal return saham pada perusahaan manufaktur yang terdaftar di Bursa Efek Indonesia menyimpulkan bahwa arus kas operasi, arus kas investasi, laba kotor, dan ukuran perusahaan tidak berpengaruh signifikan terhadap abnormal return, sedangkan arus kas pendanaan mempunyai pengaruh positif dan signifikan terhadap abnormal return. Wahyuddin dan Setiawaty (2011) meneliti pengaruh arus kas terhadap abnormal return saham dan menyimpulkan arus kas operasi, arus kas pendanaan, dan arus kas investasi mempunyai pengaruh positif signifikan terhadap abnormal return saham.

Sejumlah penelitian terdahulu tersebut menunjukan hasil yang berbeda dalam pengaruh arus kas dan laba akuntansi terhadap abnormal return. Hal ini mendorong dilakukannya penelitian lebih lanjut mengenai konsistensi pengaruh arus kas dan laba akuntansi terhadap abnormal return saham.

\section{TINJAUAN PUSTAKA}

Laporan Arus Kas. Laporan arus kas adalah laporan yang menunjukan aliran sumber ekonomi perusahaan, memberikan informasi tentang sumber penerimaan kas dan pengeluaran kas perusahaan dalam periode tertentu. Tujuan utama arus kas adalah menyediakan informasi yang relevan mengenai penerimaan dan pembayaran kas sebuah perusahaan selama suatu periode, untuk meraih tujuan ini laporan arus kas melaporkan kas yang mempengaruhi operasi salama suatu periode, transaksi investasi, transaksi pembiayaan dan kenaikan atau penurunan bersih kas selama satu periode (Kieso, at al., 2008). Laporan arus kas digunakan oleh manajemen untuk mengevaluasi kegiatan operasional yang telah berlangsung dan merencanakan aktivitas investasi dan pembiayaan dimasa yang akan datang. Macam-macam arus kas berdasarkan aktivitasnya adalah sebagai berikut :

A. Arus kas operasi

Menurut Dewan Standar Akuntansi Keuangan Ikatan Akuntansi Indonesia, arus kas yang utama dalam pelaporan arus kas adalah arus kas yang terkait dengan kegiatan operasi karena jumlah arus kas yang timbul dari aktivitas operasi adalah indikator utama untuk menentukan apakah entitas telah menghasilkan arus kas yang cukup untuk melunasi pinjaman, memelihara kemampuan operasi entitas, membayar deviden dan melakukan investasi baru tanpa bantuan sumber pendanaan dari luar, informasi tentang komponen spesifik atas arus kas operasi historis adalah berguna, dalam hubungannya dengan informasi lain dalam memperkirakan arus kas operasi masa depan (Ikatan Akuntansi Indonesia, 2014).

Arus kas aktivitas operasi diperoleh dari aktivitas penghasil utama pendapatan perusahaan, biasanya berasal dari transaksi dan peristiwa lain yang mempengaruhi laba atau rugi bersih perusahaan. Beberapa contoh arus kas dari aktivitas operasi adalah :

1. Penerimaan kas dari penjualan barang dan jasa.

2. Penerimaan kas dari royalti, fee, komisi dan pendapatan lain.

3. Pembayaran kas kepada pemasok barang dan jasa.

4. Penerimaan dan pembayaran kas oleh perusahaan asuransi sehubungan dengan premi, klaim, anuitas dan manfaat asuransi lainnya. 
5. Pembayaran kas kepada karyawan.

6. Pembayaran kas atau penerimaan kembali (restitusi) pajak penghasilan kecuali jika dapat diindentifikasikan secara khusus sebagai bagian dari aktivitas pendanaan dan investasi.

7. Penerimaan dan pembayaran kas dari kontrak yang diadakan untuk tujuan transaksi usaha dan perdagangan.

B. Arus kas investasi

Menurut Dewan Standar Akuntansi Keuangan Ikatan Akuntansi Indonesia, arus kas investasi adalah arus kas yang timbul dari aktivitas investasi, arus kas tersebut mempresentasikan sejauh mana pengeluaran yang telah terjadi untuk sumber daya yang diintensikan untuk menghasilkan penghasilan dan arus kas masa depan (Ikatan Akuntansi Indonesia, 2014).

Aktivitas investasi adalah aktivitas perolehan dan pelepasan atas instrument keuangan yang bukan bertujuan untuk diperdagangkan pada perusahaan, pengungkapan terpisah arus kas yang berasal dari aktivitas investasi perlu dilakukan untuk mencerminkan penerimaan dan pengeluaran kas sehubungan dengan sumber daya yang bertujuan untuk menghasilkan pendapatan dana arus kas masa depan. Beberapa contoh arus kas dari aktivitas investasi adalah :

1. Pembayaran kas untuk memperoleh aset tetap, aset tak berwujud, dan aset jangka panjang lain, pembayaran ini termasuk dalam kaitannya dengan biaya pengembangan yang dikapitalisasi dan aset tetap yang dibangun sendiri.

2. Penerimaan kas dari penjualan aset tetap, aset tak berwujud, dan aset jangka panjang lain.

3. Pembayaran kas untuk memperoleh instrumen utang atau instrumen ekuitas entitas lain dan kepentingan dalam ventura bersama (selain pembayaran kas untuk instrumen yang dianggap setara kas atau instrumen yang dimiliki untuk tujuan diperdagangkan atau diperjualbelikan).

4. Penerimaan kas dari penjualan utang atau instrumen ekuitas entitas lain dan kepentingan dalam ventura bersama (selain pembayaran kas untuk instrumen yang dianggap setara kas atau instrumen yang dimiliki untuk tujuan diperdagangkan atau diperjualbelikan).

5. Uang muka dan pinjaman yang diberikan kepada pihak lain (selain uang muka dan pinjaman yang diberikan oleh lembaga keuangan).

6. Penerimaan kas dari pelunasan uang muka dan pinjaman yang diberikan kepada pihak lain (selain uang muka dan pinjaman yang diberikan oleh lembaga keuangan).

7. Pembayaran kas untuk future contracts, forward contracts, option contracts, kecuali jika kontrak tersebut memiliki untuk tujuan diperdagangkan atau diperjualbelikan, atau jika pembayaran tersebut diklasifikasi sebagai aktivitas pendanaan.

8. Penerimaan kas dari future contracts, forward contracts, option contracts, kecuali jika kontrak tersebut memiliki untuk tujuan diperdagangkan atau diperjualbelikan, atau jika pembayaran tersebut diklasifikasi sebagai aktivitas pendanaan.

C. Arus kas pendanaan

Menurut Dewan Standar Akuntansi Keuangan Ikatan Akuntansi Indonesia, aktivitas pendanaan adalah aktivitas di mana kas yang diperoleh perusahaan dibayarkan kembali kepada pemilik kas (investor atau kreditur) yang menimbulkan perubahan dalam jumlah serta komposisi modal dan pinjaman perusahaan (Ikatan Akuntansi Indonesia, 2014). 
Pengungkapan terpisah dari aktivitas pendanaan perlu dilakukan sebab berguna untuk memprediksi klaim terhadap arus kas masa depan oleh pemasok modal perusahaan. Beberapa contoh arus kas dari aktivitas pendanaan adalah :

1. Penerimaan kas dari penerbitan saham atau instrument ekuitas lain.

2. Pembayaran kas kepada pemilik untuk memperoleh atau menebus saham entitas.

3. Penerbitan kas dari penerbitan obligasi, pinjaman, wesel, hipotek, dan pinjaman jangka pendek dan jangka panjang lainnya.

4. Pelunasan pinjaman.

5. Pembayaran kas oleh lessee untuk mengurangi saldo liabilitas yang berkaitan dengan sewa pembiayaan.

Dalam penelitian ini, arus kas yang digunakan adalah arus kas bersih yaitu total dari subtotal perkomponen arus kas, karena komponen arus kas saling berhubungan seperti ketika arus kas operasi tidak bisa mencukupi kegiatan operasi maka bisa ditutupi dengan arus kas investasi dengan menjual aktiva tetapnya, atau bisa dengan arus kas pendanaan berupa investasi dari investor dan pinjaman dari bank. Total arus kas perkomponen memang dibutuhkan untuk melihat sejauh mana kegiatan operasi, investasi pendanaan dipergunakan akan tetapi hasil akhir dari laporan arus kas sendiri adalah total arus kas bersih yaitu total dari perkomponen arus kas.

Laba Akuntansi. Harahap (2012) menyatakan bahwa laba akuntansi adalah perbedaan relialisasi penghasilan yang berasal dari transaksi perusahaan pada periode tertentu dikurangi dengan biaya biaya yang dikeluarkan untuk mendapatkan penghasilan itu. Belkaoui (2012) mendefinisikan bahwa laba mengandung lima sifat berikut :

1. Laba akuntansi didasarkan pada transaksi yang benar benar terjadi yaitu timbulnya hasil dan biaya untuk mendapatkan hasil tersebut.

2. Laba akuntansi didasarkan pada porsulat periodik laba itu, artinya merupakan prestasi perusahaan itu pada periode tertentu.

3. Laba akuntansi didasarkan pada prinsip revenue yang memerlukan batasan tersendiri tentang apa yang termasuk hasil.

4. Laba akuntansi memerlukan perhitungan terhadap biaya dalam bentuk historis yang dikeluarkan perusahaan untuk mendapatkan hasil tertentu.

5. Laba akuntansi didasarkan pada prinsip matching artinya hasil dikurangi biaya yang diterima atau dikeluarkan dalam periode yang sama.

Harrison Jr., et al. (2011) menggolongkan laba akuntansi menjadi tiga golongan berikut yaitu :

1. Laba kotor adalah selisih dari pendapatan dikurangi dengan harga pokok barang terjual. Harga pokok barang terjual adalah semua biaya yang dikontribusikan untuk mendapatkan atau membuat barang tersebut.

2. Laba operasi adalah selisih dari laba kotor dengan beban operasi operasi, beban operasi adalah beban yang terus dikeluarkan oleh entitas, selain beban langsung barang dagang dan biaya lainnya yang berkaitan langsung dengan penjualan.

3. Laba bersih adalah selisih seluruh pendapatan entitas dengan seluruh biaya yang ada yang terjadi pada entitas untuk periode yang bersangkutan.

Dalam penelitian ini, digunakan laba bersih yaitu laba tahun berjalan karena laba tahun berjalan perusahaan merupakan hasil utama yang terjadi berdasarkan kegiatan utama perusahaan dengan segala biaya yang dikeluarkan perusahaan. 


\begin{abstract}
Abnormal Return. Menurut Hartono (2013), abnormal return atau excess return merupakan kelebihan dari return yang sesungguhnya dengan return normal. Return normal merupakan return ekspektasi (return yang diharapkan investor) sehingga dapat disimpulkan sebagai berikut : $r n_{i, t}=r_{i, t}-e\left(r_{i, t}\right)$

Keterangan :

$\mathrm{rtn}_{\mathrm{i}, \mathrm{t}} \quad$ : abnormal return sekuritas ke-i pada periode peristiwa ke-t.

$r_{i, t} \quad$ : return realisasi yang terjadi untuk sekuritas ke-i pada periode peristiwa ke-t.

e $\left(r_{i, t}\right)$ : return ekspektasi sekuritas ke-i pada periode peristiwa ke-t.
\end{abstract}

Return realisasi atau return sesungguhnya merupakan return yang terjadi pada waktu ke-t yang merupakan selisih harga sekarang relatif terhadap harga sebelumnya atau dapat dihitung dengan rumus :

$$
R_{\text {it }}=\frac{P_{t}-p_{t-1}}{e_{t-1}}
$$

Pada persamaan tersebut, $\mathrm{p}_{\mathrm{t}}$ merupakan harga saham perusahaan i pada periode $\mathrm{t}$ dan $\mathrm{p}_{\mathrm{t}-1}$ merupakan harga saham perusahaan $\mathrm{i}$ pada periode $\mathrm{t}-1$, sedangkan return ekspektasi merupakan return yang harus diestimasi. Return ekpektasi atau return yang diharapkan dihitung dengan metode market adjusted model (model sesuaian pasar) menganggap bahwa penduga yang terbaik untuk menginvestasi return suatu sekuritas adalah return indeks pasar pada saat tersebut. Dengan menggunakan model ini, maka tidak perlu menggunakan periode estimasi untuk membentuk model estimasi, karena return sekuritas yang diestimasi adalah sama dengan return indeks pasar. Abnormal return untuk masing-masing sekuritas menggunakan market adjusted model (model sesuaian pasar) dapat dihitung dengan mengurangkan return yang terjadi untuk masing masing sekuritas dengan return indeks pasar pada hari yang sama.

Investor dalam menginvestasikan dananya pasti menginginkan pengembalian yang tinggi atas investasi dananya. Untuk menilai kinerja suatu entitas, para investor dapat melihat laporan keuangan yang memberikan informasi tentang posisi keuangan, laporan perubahan posisi keuangan catatan dan laporan lain yang merupakan bagian integral dari bagian keuangan laporan. Dengan penggunaan arus kas dan laba sebagai alat prediksi diharapkan dapat memberikan informasi sebagai alat untuk menaksir dan menduga aliran kas untuk pembagian deviden dan sebagai alat menaksir kemampuan entitas dalam menerima laba pada periode mendatang. Arus kas yang digunakan adalah kenaikan arus kas bersih entitas karena laporan arus kas secara keseluruhan untuk mengetahui seberapa besar arus kas akhir didapatkan perusahaan selama periode tertentu dan laba akuntansi yang menggunakan laba bersih yaitu laba tahun berjalan karena laba tahun berjalan perusahaan merupakan hasil utama yang terjadi berdasarkan kegiatan utama perusahaan dengan segala biaya yang dikeluarkan perusahaan. Informasi dari pelaporan arus kas dan laporan laba rugi diharapkan akan menimbulkan reaksi pasar, reaksi pasar ditunjukan dengan adanya perubahan harga pasar entitas tertentu yang cukup besar pada saat publikasi laporan tersebut. Sejumlah penelitian terdahulu menunjukkan hasil yang beragam sehingga peneliti tertarik untuk melakukan studi lebih lanjut mengenai konsistensi pengaruh arus kas dan laba akuntansi terhadap abnormal return saham.

Arus kas merupakan indikator utama dalam menentukan apakah perusahaan telah menghasilkan arus kas yang cukup untuk menutupi segala pengeluaran yang dibutuhkan 
untuk kegiatan perusahaannya, maka semakin tinggi nilai arus kas maka semakin tinggi juga pengembalian atas investasi yang dilaksanakan pada perusahaan tersebut.

$\mathrm{H} 1$ : Arus kas berpengaruh positif terhadap abnormal return.

Laba akuntasi merupakan hasil perhitungan atas kegiatan perusahaan dalam periode tertentu, sehingga semakin tinggi laba akuntansi yang dihasilkan semakin tinggi juga pengembalian atas investasi yang dilaksanakan pada perusahaan tersebut.

H2 : Laba akuntansi berpengaruh positif terhadap abnormal return.

Arus kas dan laba akuntansi secara simultan dapat mempengaruhi pengembalian atas investasi yang dilaksanakan. Dengan demikian semakin tinggi arus kas dan laba akuntansi yang dihasilkan secara simultan, semakin tinggi juga pengembalian atas investasi yang dilaksanakan pada perusahaan tersebut.

H3 : Arus kas dan laba akuntansi berpengaruh positif terhadap abnormal return.

\section{METODE PENELITIAN}

Jenis penelitian ini termasuk penelitian kausalitas kuantitatif. Populasi dalam penelitian ini adalah 142 perusahaan manufaktur yang terdaftar Bursa Efek Indonesia pada tahun 2017. Teknik sampling adalah purposive sampling, dengan mendasarkan pada kriteria perusahaan tidak pernah delisting dari Bursa Efek Indonesia, konsisten mengungkapkan data variabel terkait dalam penelitian ini, dan tidak pernah mengalami rugi. Berdasarkan kriteria purposive sampling tersebut diperoleh 46 perusahaan sebagai sampel. Data yang digunakan dalam penelitian ini berupa data sekunder, yang diperoleh dari publikasi Indonesian Capital Market Directory.

Variabel dependen dalam penelitian ini adalah abnormal return, yang merupakan kelebihan dari return yang sesungguhnya dengan return normal. Adapun variabel independen terdiri dari dua variabel. Variabel independen pertama adalah arus kas yang diukur dengan arus kas bersih yaitu total dari subtotal perkomponen arus kas. Sedangkan variable independen kedua adalah laba akuntansi, yaitu perbedaan relialisasi penghasilan yang berasal dari transaksi perusahaan pada periode tertentu dikurangi dengan biaya-biaya yang dikeluarkan untuk mendapatkan penghasilan itu.

Selanjutnya untuk menguji pengaruh variabel independen terhadap variabel dependen, diakukan analisis Regresi Linier Berganda atas model berikut :

Abnormal return $=\beta_{0}+\beta_{1}$ Arus kas $+\beta_{2}$ Laba akuntansi $+e$

\section{HASIL DAN PEMBAHASAN}

Uji normalitas. Pengujian normalitas bertujuan untuk menguji apakah variabel independen yaitu abnormal return saham dan variabel dependen yaitu arus kas dan laba akuntansi atau keduanya yang mempunyai distribusi normal atau mendekati normal. Dalam pengujian ini ditemukan baik histogram maupun grafik normal plot hampir mendekati distribusi yang normal. Pada prinsipnya normalitas dapat dideteksi dengan penyebaran data (titik) pada sumbu diagonal dari grafik atau dengan melihat histogram dari residual. 
Gambar 1

Hasil Uji Normalitas



Uji multikolonieritas. Uji multikolinearitas bertujuan untuk menguji apakah dalam model regresi ditemukan adanya korelasi antar variabel independen. Jika terjadi korelasi maka dinamakan terdapat problem multikolinearitas. Mendeteksi adanya multikolinearitas adalah dengan cara melihat nilai variance inflation factor (VIF) berada di sekitar angka 1 dan tolerance mendekati angka 1.

Tabel 1

Hasil Uji Multikolinieritas

\begin{tabular}{lllc} 
Coefficients $^{\mathrm{a}}$ & & \multicolumn{2}{c}{ Collinearity statistics } \\
Model & & Tolerance & VIF \\
& & & \\
\multirow{2}{*}{1} & (constant) & .995 & 1.005 \\
& Arus kas & .995 & 1.005 \\
\hline
\end{tabular}

a. Dependent variable: abnormal return

Berdasarkan tabel diatas dapat disimpulkan variabel independen arus kas dan laba akuntansi dapat dipastikan tidak mengalami multikolonieritas, hal tersebut terlihat dari hasil VIF yang bernilai 1,005 karena nilai $\mathrm{VIF}<10$ dan nilai tolerance sebesar 0,995 di mana nilai tolerance $<0,1$.

Uji autokorelasi. Uji autokorelasi bertujuan untuk melihat apakah dalam model regresi linier terdapat korelasi antara variabel bebas dengan variabel terikat. Model regresi yang baik adalah yang bebas dari autokorelasi, pengujian ini menggunakan Durbin-Watson (Dw-Test) yang dijelaskan pada tabel 2 berikut.

Tabel 2

Hasil Uji Autokorelasi Model summary ${ }^{b}$

\begin{tabular}{cccccc}
\hline Model & $\mathrm{R}$ & $\begin{array}{c}\mathrm{R} \\
\text { square }\end{array}$ & $\begin{array}{c}\text { Adjusted } \mathrm{r} \\
\text { square }\end{array}$ & $\begin{array}{c}\text { Std. Error of } \\
\text { the estimate }\end{array}$ & $\begin{array}{c}\text { Durbin- } \\
\text { watson }\end{array}$ \\
\hline 1 & $.231^{\mathrm{a}}$ & .054 & .045 & .55545 & 1.956 \\
\hline
\end{tabular}

a. Predictors: (constant), laba akuntansi, arus kas

b. Dependent variable: abnormal ret.saham 
Berdasarkan tabel 2, hasil uji Durbin-Watson menunjukan 1,956. Nilai Durbin-Watson tersebut dibandingkan dengan nilai tabel Durbin-Watson dengan jumlah data $(n)=230, k=2$ yang menghasilkan nilai $d l=1.77525$ dan nilai $d u=1.79270$ dan nilai $4-d u=2.2073$ jika melihat ketentuan $\mathrm{du}<\mathrm{d}<4$-du atau $1.79270<1.956<2.2073$ maka dapat disimpulkan bahwa tidak ada autokorelasi positif atau negatif.

Uji heteroskedastisitas. Uji heteroskedastisitas digunakan untuk mengetahui apakah terdapat perbedaan antara variance dari observasi yang satu dengan observasi yang lain. Persamaan regresi yang baik adalah yang tidak terjadi heteroskedastisitas. Salah satu cara untuk mendeteksi terjadinya heteroskedastisitas adalah dengan melihat grafik scatterplot antara nilai prediksi variabel dependen zpred dengan ini residualnya sresid (Ghozali, 2011). Dasar analisis grafik scatterplot yaitu :

1. Jika ada pola tertentu, seperti titik-titik yang ada membentuk pola tertentu yang teratur (bergelombang, melebar kemudian menyempit), maka mengidentifikasikan telah terjadi heteroskedastisitas.

2. Jika tidak ada pola yang jelas dan titik-titik tidak menyebar di atas dan di bawah angka nol pada sumbu y, maka tidak terjadi heteroskedastisitas.

Gambar 2

Hasil Uji Heteroskedastisitas

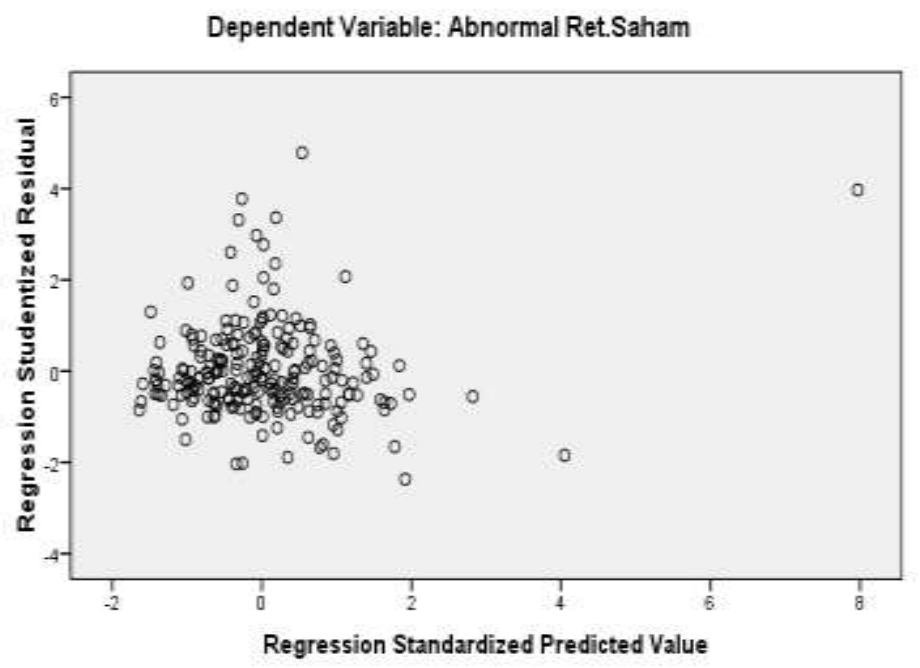

Tabel 3

Regresi Linier Berganda

\begin{tabular}{|c|c|c|c|c|c|}
\hline & \multirow{2}{*}{ Model } & \multicolumn{2}{|c|}{ Unstandardized Coefficients } & \multirow[t]{2}{*}{$\mathrm{t}$} & \multirow[t]{2}{*}{ Sig. } \\
\hline & & B & Std. Error & & \\
\hline \multirow{3}{*}{1} & (Constant) & -1.127 & .460 & -2.448 & .015 \\
\hline & Arus Kas & -.009 & .004 & -2.188 & .030 \\
\hline & Laba Akuntansi & .048 & .018 & 2.668 & .008 \\
\hline
\end{tabular}

Analisis Regresi Linier Berganda. Berdasarkan tabel 3 diperoleh persamaan regresi linier berganda sebagai berikut :

$$
Y=-1,127-0,009 X_{1}+0,048 X_{2}
$$


Persamaan tersebut bermakna :

1. Nilai konstanta negatif, hal ini menunjukan abnormal return saham yang dihitung dengan persamaan regresi tersebut akan lebih kecil daripada yang diharapkan; dan diasumsikan bahwa jika arus kas dan laba akuntansi nol maka abnormal return saham akan negatif.

2. Koefisien arus kas $\left(X_{1}\right)$ menunjukkan angka negatif, hal ini berarti jika arus kas mengalami penurunan maka abnormal return saham akan mengalami kenaikan sebesar 0,009 ; dengan asumsi ceteris paribus. Nilai signifikansi variabel arus kas sebesar 0,30 lebih kecil daripada tolok ukur 0,50 sehingga pengaruh arus kas terhadap abnormal return adalah signifikan.

3. Koefisien laba akuntansi $\left(\mathrm{X}_{2}\right)$ menunjukkan angka positif, hal ini berarti jika laba akuntansi mengalami penurunan maka abnormal return saham juga akan mengalani penurunan sebesar 0,048; dengan asumsi ceteris paribus. Nilai signifikansi variabel laba akuntansi sebesar 0,08 lebih kecil daripada tolok ukur 0,50 sehingga pengaruh laba akuntansi terhadap abnormal return adalah signifikan.

Tabel 4

Hasil Uji F

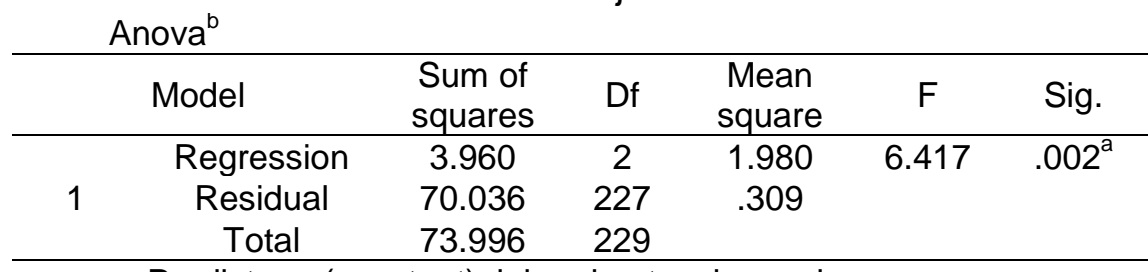

a. Predictors: (constant), laba akuntansi, arus kas

b. Dependent variable: abnormal return

Berdasarkan tabel 4 diperoleh nilai $f_{\text {hitung }} 6,417$ dan sig 0,002, sedangkan $f_{\text {tabel }}$ sebesar 3,035617. Karena $f_{\text {hitung }}>f_{\text {tabel }}$ dan nilai sig $0,002<$ sig 0,05 maka berarti variabel arus kas dan laba akuntansi secara simultan berpengaruh positif signifikan terhadap abnormal return saham.

Tabel 5

Koefisien Determinasi

Model summary

\begin{tabular}{lllll}
\hline Model & $\mathrm{R}$ & R square & $\begin{array}{l}\text { Adjusted } \mathrm{r} \\
\text { square }\end{array}$ & $\begin{array}{l}\text { Std. Error of the } \\
\text { estimate }\end{array}$ \\
\hline 1 & $.231^{\mathrm{a}}$ & .054 & .045 & .55545 \\
\hline
\end{tabular}

a. Predictors: (constant), laba akuntansi, arus kas

b. Dependent variable: abnormal return

Koefisien determinasi dimaksudkan untuk menganalisis seberapa besar variasi variabel independen dapat menjelaskan variasi variabel dependen. Koefisien determinasi diukur menggunakan adjusted $R$ square. Berdasarkan Tabel 5 , adjusted $R$ square adalah sebesar 0.045 atau 4,5\%. Hal ini berarti sebesar 4,5\% variasi arus kas dan laba akuntansi dapat menjelaskan variasi abnormal return saham, sedangkan sisanya sebesar $95,5 \%$ dijelaskan oleh faktor-faktor lain di luar model penelitian ini.

Berdasarkan penelitian yang telah dilakukan dan didasarkan hasil pengolahan data, maka dalam penelitian ini ada beberapa hal yang dapat dijelaskan sebagai berikut : 
1. Pengaruh Arus Kas terhadap Abnormal Return Saham.

Variabel arus kas menunjukkan pengaruh negatif signifikan terhadap abnormal return saham, terlihat pada nilai signifikansi sebesar 0,030 di bawah tolok ukur signifikansi 0,05. Hal ini menunjukan bahwa penurunan pada total arus kas akan mendorong peningkatan pada abnormal return saham, begitu pula sebaliknya. Kejadian ini memungkinkan bahwa saat nilai arus kas turun pada periode bersangkutan, perusahaan telah melaporkan pembayaran deviden kepada investor ataupun pembayaran hutang kepada kreditor sehingga total arus kas menjadi lebih rendah. Dengan demikian arus kas dapat dijadikan sebagai indikator dalam menentukan abnormal return. Pelaporan kenaikan dan penurunan arus kas bersih memiliki urgensi untuk mengetahui dan memahami apa yang terjadi pada arus kas sebagai sumber daya perusahaan untuk menilai kemampuan perusahaan dalam memenuhi kewajibannya. Hasil penelitian ini didukung oleh penelitian Wahyuddin dan Setiawaty (2011) serta Endang I.T. (2008).

2. Pengaruh Laba Akuntansi terhadap Abnormal Return Saham.

Variabel laba akuntansi menunjukan pengaruh positif signifikan terhadap abnormal return saham, terlihat pada nilai signifikansi sebesar 0,008 di bawah tolok ukur signifikansi 0,05. Hal ini menunjukan bahwa laba akuntansi dapat dijadikan sebagai indikator dalam memprediksi abnormal return saham. Pelaporan laba akuntansi berisi informasi kinerja perusahaan dalam periode tertentu yang menentukan keberhasilan suatu perusahaan, mengindikasikan bahwa calon investor memberikan respon positif terhadap perusahaan yang mengumumkan laba. Kemungkinan perusahaan mampu menghasilkan laba lebih dari laba yang telah diharapkan yang diikuti dengan bertambahnya pembayaran deviden para investor. Hasil penelitian ini sesuai dengan penelitian Amalia, et. al. (2012) dan Djam'an, et. al. (2011).

3. Pengaruh Arus Kas dan Laba Akuntansi terhadap Abnormal Return Saham.

Variabel arus kas dan laba akuntansi secara simultan menunjukan pengaruh positif signifikan terhadap abnormal return saham. Hal ini terbukti dari nilai signifikasin sebesar 0.002 di bawah tolok ukur signifikansi 0,05. Temuan ini menunjukkan bahwa informasi laporan keuangan perusahaan memiliki andil dalam keputusan investor dalam pengambilan keputusan investasi. Temuan ini didukung oleh penelitian Yocelyn dan Christiawan (2012).

\section{KESIMPULAN}

Berdasarkan hasil analisis dan pembahasan, dapat diambil kesimpulan bahwa arus kas secara parsial berpengaruh negatif signifikan terhadap abnormal return saham, laba akuntansi secara parsial berpengaruh positif signifikan terhadap abnormal return saham, serta arus kas dan laba akuntansi secara simultan berpengaruh positif signifikan terhadap abnormal return saham.

Penelitian lebih lanjut di waktu yang akan datang disarankan untuk meneliti kembali pengaruh arus kas dan laba akuntansi terhadap abnormal return saham untuk menguji konsistensi hasil penelitian dengan menambahkan sampel penelitian pada sector-sektor selain manufaktur. Selain itu, penelitian selanjutnya diharapkan menggunakan periode penelitian yang lebih panjang sehingga pengaruh masing-masing variabel dapat dikaji lebih mendalam. Selanjutnya perlu juga dilakukan penelitian yang menghitung abnormal return dengan menggunakan model selain market adjusted model. Koefisien determinasi 
menunjukkan rendahnya kontribusi variasi variabel independen dalam menjelaskan variasi variabel dependen penelitian ini. Hal ini mengindikasikan bahwa masih terdapat variabelvariabel lain di luar model penelitian ini yang mempunyai potensi pengaruh lebih besar terhadap abnormal return saham. Variabel-variabel lainnya tersebut layak untuk dikaji lebih mendalam.

\section{DAFTAR PUSTAKA}

Agustina, L. dan Kianto, F. 2012. Pengaruh Informasi Laba Akuntansi Terhadap Abnormal Return Pada Perusahaan Yang Tergabung Dalam Indeks LQ45. Skripsi. Bandung: Universitas Kristen Maranatha.

Amalia, R., Arfan, M. dan Shabri, M. 2012. Pengaruh Laba, Pengungkapan Corporate Social Responbility Dan Profitabilitas Terhadap Abnormal Return Saham. Skripsi. Banda Aceh: Universitas Syiah Kuala.

Belkaoui, A.R. 2012. Teori Akuntansi. Jakarta: Salemba Empat.

Darmawan, E. S. 2000. Laba Akuntansi dan Laba Tunai dengan Deviden Kas. Skripsi. Jakarta: Universitas Tarumanegara.

Dewan Standar Akuntansi Keuangan. 2014. Standar Akuntansi Keuangan Per Efektif Tahun 1 Januari 2015. Jakarta: Ikatan Akuntansi Indonesia.

Djam'an, N., Pagalung, G. dan Tawakkal. 2011. Pengaruh Informasi Laporan Arus Kas, Laba dan Size Perusahaan Terhadap Abnormal Return. Skripsi.

Endang, I. T. 2008. Pengaruh Kandungan Informasi Arus Kas, Komponen Arus Kas dan Laba Akuntansi Terhadap Harga dan Return Saham. Skripsi. Semarang : Universitas Diponogoro.

Ghozali, I. 2011. Aplikasi Analisis Multivariate dengan Program IBM SPSS 19. Semarang: Badan Penerbit Universitas Diponogoro.

Harahap, S. S. 2012. Teori Akuntansi. Jakarta: PT Rajagrafindo Persada.

Harrison Jr, et. al. 2012. Akuntansi Keuangan, Jakarta : Erlangga.

Hartono, J. 2013. Teori Portopolio dan Analisis Investasi. Yogyakarta : BPFE Yogyakarta.

Kieso, D. E. et. al. 2008. Akuntansi Intermediate. Jakarta : Erlangga.

Nelvianti. 2012. Pengaruh Informasi Arus Kas, Laba dan Ukuran Perusahaan Terhadap Abnormal Return Saham Pada Perusahaan Manufaktur Yang Terdaftar Di Bursa Efek Indonesia. Skripsi. Padang :Universitas Negeri Padang.

Rudianto. 2008. Pengantar Akuntansi, Jakarta: Erlangga.

Sanusi, A. 2011. Metodologi Penelitian Bisnis. Jakarta : Salemba Empat.

Sugiono. 2014. Metode Kombinasi (Mixed Methods). Bandung : Alfabeta.

Sunarto, L. 2014. Pengaruh Informasi Laporan Arus Kas, Laba Kotor, Ukuran Perusahaan Dan Nilai Perusahaan Terhadap Abnormal Return Saham Pada Perusahaan Tekstil Dan Garment Yang Terdaftar Di BEI 2010-201. Skripsi. Tanjungpinang : Universitas Maritim Raja Ali Haji.

Umdiana, N. 2014. Pengaruh Kandungan Informasi Laba, Arus Kas Operasi, Deviden, Ukuran Perusahaan Dan Tingkat Inflasi Terhadap Abnormal Return. Jurnal Akuntansi Volume 1 No. 1.

Wahyuddin dan Setiawaty. 2011. Pengaruh Arus Kas Terhadap Return Saham. Jurnal Akuntansi Vol 1 No. 1. 